\title{
ISLET-CELL TUMOURS AND PEPTIC ULCERATION
}

\author{
James B. Gibson, M.D. M.R.C.P.E.(Edin.) \\ Lecturer in Pathology, Queen's University of Belfast \\ and Richard B. Welbourn, M.A., M.D.(Camb.), F.R.C.S. \\ Professor of Surgical Science, Queen's University of Belfast; Surgeon, Royal Victoria Hospital, Belfast
}

Organic hyperinsulinism was recognized clinically soon after the discovery of insulin ${ }^{37}$ and it was found that surgical removal of a tumour of the islets of Langerhans would cure it. ${ }^{15}$ This is an old and well-known story but the islet cells, their secretions and their tumouri, are again receiving attention, though for other reasons. Islet-cell tumours, especially those which do not secrete insulin, are sometimes associated with fulminating peptic ulcers, and functioning lesions of other endocrine glands sometimes accompany those in the pancreas.

\section{The Cells of the Islets and Their Secretions}

Four types of cell, $\alpha, \beta, \gamma$ and $\delta$, can be distinguished by their staining reactions. ${ }^{17}$ The $\beta$ cells are the most numerous and secrete insulin, which can be seen as granules in the cytoplasm. The $\alpha$ cells are less frequent. They probably secrete glucagon, a hormone which plays a part in carbohydrate metabolism. Glucagon antagonizes insulin by stimulating the breakdown of glycogen in the liver and so raising the concentration of glucose in the blood. It shares with insulin the capacity to promote utilization of glucose by the other tissues. The $\delta$ cells do not take specific stains and their function is unknown. The $\gamma$ cells are not found in man.

\section{Pathology of the Islet cells}

The following primary disorders of the islet cells, apart from those associated with diabetes, have been recognized:-

(i) Hyperfunction without morphological change.

(ii) Generalized hyperplasia.

(iii) Discrete adenoma.

(iv) Generalized adenomatosis.

(v) Carcinoma.

The lesions occur alone or less commonly in combination and may involve the $\alpha$ or the $\beta$ cells, or both. The cells of tumours frequently exhibie no specific staining reaction. Tumours of $\alpha$ cells are indistinguishable from $\beta$-cell growths by the routine methods of examination, although identification by special stains may be possible. Theo structure of islet-cell tumours has been well described and illustrated by several authors, includ $\bar{z}$ ing Duff and Murray, ${ }^{5}$ Spencer, ${ }^{28}$ and Evans, who have also discussed the criteria for the diagnosis of malignancy. Some tumours with histological features suggesting malignancy not behave in this fashion. Among the frand malignant cases there are reports of patients sw् viving with proved metastases for several years in reasonable health. The tumours may rarely be्ष large enough to be palpable or sometimes so smalp that they can easily escape detection.

The adenomata vary considerably in structure $\overrightarrow{\overrightarrow{0}}$ The best differentiated are composed of ribbons or trabeculae of islet cells, closely related to smale blood vessels, which interdigitate with the trabeculae. Occasionally a rough acinar arrangemene is found. This structure caricatures rather thant. reproduces normal islet architecture; the presence of a fibrous capsule round these well differentiate tumours also serves to distinguish them from? islets enlarged by a simple hyperplasia. A solid form of architecture without any well markef arrangement is also common. It typifies a less differentiated growth, which is often poorly en capsulated, and it resembles that found in malignant islet-cell tumours. Islet-cell tumours frequently undergo degenerative changes but, in the case of the $\beta$-cell tumours at least, these $\mathrm{do}^{\omega}$ not alter endocrine activity. ${ }^{5}$ In the solid type of adenoma, haemorrhage may occur and, in the trabecular form particularly, a diffuse hyaline sclerosis is often present, especially at the periphery of the tumour. The hyaline tissue may eventually calcify. Duff and Murray ${ }^{5}$ noted that the hyaline fibrous tissue was laid down initially 
between the trabeculae and their blood vessels, and our own observations confirm this.

Sometimes the islet-cell lesions are associated with tumours or hyperplasias of other endocrine glands in a syndrome of multiple endocrine adetiopathy. The anterior pituitary, the parathytoids and the adrenal cortices are affected most often; adenomata of the thyroid have been reported occasionally. ${ }^{31}$ Wermer $^{35}$ detected morphological differences between the endocrine lesions in this syndrome and those in conditions in which the glands are affected singly. We have been unable to confirm the specificity of these differences in our material. The pluriglandular syndrome is often hereditary.

Where a detailed search is made, islet-cell lesions may be found in I-2 per cent. of routine autopsies. ${ }^{28}$ Many of these are silent and not associated with other lesions. In overt cases the following clinical manifestations may be found (Table I):

(i) Hyperinsulinism.

(ii) Features of other endocrine lesions.

(iii) Simple peptic ulceration.

(iv) Fulminating peptic ulcer (Zollinger-Ellison syndrome).

Table I.-Correlation BetWeEn Islet-cell Lesions and Clinical features

\begin{tabular}{|c|c|c|c|c|}
\hline \multirow{3}{*}{ Clinical features } & \multicolumn{4}{|c|}{ Islet-cell Lesions } \\
\hline & \multicolumn{2}{|c|}{$\begin{array}{c}\text { Islet-cell } \\
\text { Lesions only }\end{array}$} & \multicolumn{2}{|c|}{$\begin{array}{c}\text { Multiple } \\
\text { Endocrine } \\
\text { Adenopathy }\end{array}$} \\
\hline & $\alpha$-cell & $\beta$-cell & $x$-cell & $\beta$-cell \\
\hline $\begin{array}{l}\text { Hyperinsulinism } \\
\text { Simple peptic ulcer } \\
\text { Fulminating peptic } \\
\text { ulcer } \\
\text { Hyperpituitarism and } \\
\text { or hyperparathyroi- } \\
\text { dism }\end{array}$ & $\begin{array}{l}\overline{+} \\
++\end{array}$ & $\begin{array}{l}++ \\
-\end{array}$ & $\begin{array}{c}\overrightarrow{++} \\
+\end{array}$ & $\begin{array}{c}+ \\
++ \\
+ \\
+\end{array}$ \\
\hline
\end{tabular}

\section{Hyperinsulinism}

This syndrome is well known but uncommon.14 The pancreatic lesions involve the $\beta$ cells. Usually the islet cells alone are affected, but occasionally multiple endocrine adenopathy is found. The lesions secrete excessive quantities of insulin continuously or intermittently and islet-cell tumours of this sort are sometimes called 'insulinomas.' The syndrome affects the sexes equally. It is commonest in middle age, but has been found in infants and in the aged. The clinical triad described by Whipple ${ }^{36}$ can usually be elicited; it consists of:

(i) Attacks of nervous or gastrointestinal disturbances coming on in the fasting state, associated with (ii) Hypoglycaemia with readings below $50 \mathrm{mg}$. $/ 100 \mathrm{ml}$., which is

(iii) Relieved immediately by the ingestion of glucose.

\section{Features of Other Endocrine Lesions}

Involvement of the pituitary may cause enlargement of the sella turcica, and acromegaly is an occasional feature. Parathyroid lesions may bring about an increase in the serum calcium, a decrease in the serum phosphate and urinary calculi. ${ }^{31,40}$ The adrenocortical lesions are not recognizable clinically, but they may cause an increase in the urinary steroids. ${ }^{19}$

\section{Simple Peptic Ulceration}

Peptic ulceration is a common feature of the syndrome of multiple endocrine adenopathy. The associated islet-cell lesions may affect $\alpha$ or $\beta$ cells. Usually the ulceration has no special features, but it may be of the fulminating variety described below. Multiple endocrine adenopathy appears to be determined genetically ${ }^{34}$ a family has been observed in which some of the affected members presented symptoms of peptic ulcer alone, one had symptoms of endocrine lesions alone and some had symptoms of both ulceration and endocrinopathy (A. S. Mason-personal communication). There is little evidence that any of the endocrine lesions causes the peptic ulcers; indeed, in one patient removal of both parathyroid and islet-cell tumours did not influence the ulceration. ${ }^{26}$ Occasionally other gastric lesions, such as gastritis or polyposis, are found.

Peptic ulcers appear to be extremely rare in the syndrome of hyperinsulinism when the islet cells alone are affected, and in the few cases that have been published ${ }^{16,29,20}$ the presence of lesions in other endocrine glands cannot be excluded. In fact, if peptic ulcer develops in a patient with hyperinsulinism it is almost certain that there are also lesions in other endocrine glands. The rarity of ulceration in these patients is surprising, for their spontaneous hypoglycaemia stimulates gastric hypersecretion ${ }^{27}$ just as that induced by injections of insulin does in normal subjects.

\section{Fulminating Peptic Ulcer (Zollinger-Ellison Syndrome)}

Zollinger and Ellison ${ }^{39}$ were the first to concentrate attention on the association of:

(i) A diathesis to fulminating peptic ulcer;

(ii) Gastric hypersecretion; and

(iii) An islet-cell tumour of the pancreas not composed of $\beta$ cells.

Many cases have been described in the past few years., 7 The sexes are affected equally. Most 


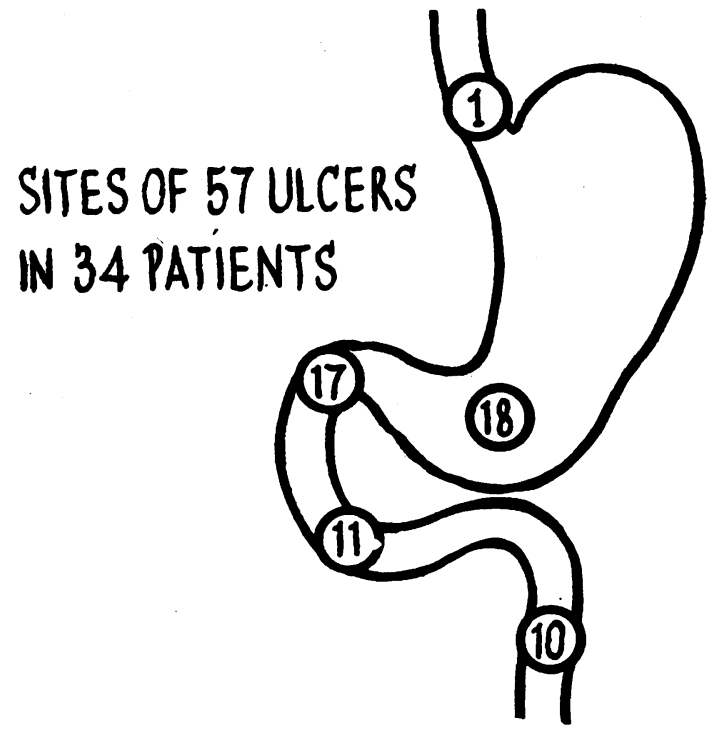

Fig. 1.-Peptic u'ceration in the Zollinger-Ellison syndrome. 12 of the 18 gastric ulcers were found in one patient. ${ }^{21}$

patients are in middle age ( 30 to 50 ) and the extremes so far reported are 19 and 78 years. ${ }^{21}$

\section{Peptic Ulcer}

The ulcers have several characteristic features. They are often multiple and in unusual sites. The review of Mackenzie et al. ${ }^{21}$ notes 57 ulcers in 34 patients (Fig. 1 ). Eleven of the ulcers were in the duodenum below the ampulla of Vater and ten were in the jejunum. A primary peptic ulcer in the jejunum would appear to be practically pathognomonic of this condition. The course of the ulceration is fulminant, checkered by serious complications and rapid recurrence after normally adequate surgical treatment, and marked by considerable loss of weight. Many patients have had more than one operation, several have had five or six, and most have died eventually from the complications of peptic ulcer or its treatment.

\section{Gastric Hypersecretion}

Gastric hypersecretion has been noted repeatedly in the Zollinger-Ellison syndrome. ${ }^{33}$ The volume and acidity of the juice tends to be greater than that found with ordinary duodenal ulcers. The resting juice often amounts to 2 to 3 litres in 12 hours and as much as 6 litres has been recorded. This juice usually contains 50 to 100 milliequivalents of $\mathrm{HCl}$ per litre and sometimes more; a $\mathrm{pH}$ of $\mathrm{I.4}$ has been recorded in the jejunum of one patient. ${ }^{30}$ The concentrations of pepsin in the serum and of uropepsin in the urine are often

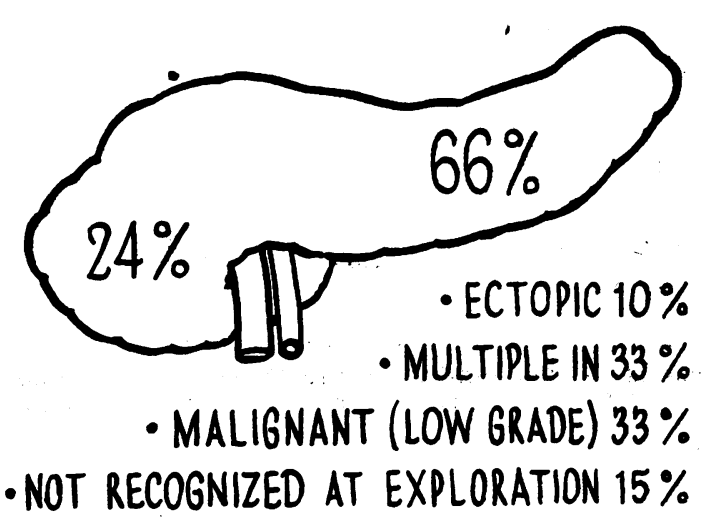

FIG. 2.-Sites of islet-cell tumours in the ZollingerEllison syndrome. ${ }^{7}$

extremely high. The characteristics of the juice are those of that secreted in response to powerful vagal stimulation, as with lesions in the brain stem, ${ }^{4}$ and it is surprising that the hypersecretion often persists after vagotomy, even when it is accompanied by radical partial gastrectomy. ${ }^{38}$

Another feature, which is related to the gastric hypersecretion and which has been noted in several patients, is gross hypertrophy of the gastric and duodenal mucosa. ${ }^{40,22}$ It may be recognize during life by $\mathrm{X}$-rays or gastroscopy or it may be found post-mortem.

Severe watery diarrhoea, sometimes associate with potassium deficiency and steatorrhoea, is an occasional symptom. ${ }^{32,30}$ It may precede the ulceration by several years. Continuous gastric aspiration may stop the diarrhoea, but is liable to cause alkalosis and tetany. ${ }^{3}$

\section{Islet-cell Lesions}

About 66 per cent. of the tumours are found in the body or tail of the pancreas, 24 per cent. in the head and ro per cent. in ectopic sites, particularly at the hilum of the spleen or around the duodenum or pyloric antrum ${ }^{7}$ (Fig. 2). The distribution in the pancreas is similar to that of insulinomas. In 33 per cent. of reported cases the tumours were multiple and in 33 per cent. they were malignant. About 15 per cent. of $\frac{D}{0}$ the tumours have escaped detection at operations in which they were sought and have been found $N$ later by the pathologist in resected pancreatic $N$ tissue or at necropsy. Lesions have been re- N ported in other endocrine glands in about a $\omega$ quarter of the cases, but information on this aspect is often incomplete and perhaps the pro- $\stackrel{\circ}{\mathbb{C}}$

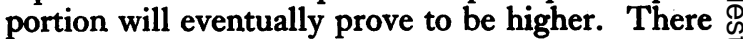
is no agreement about which islet cells form the tumours in the Zollinger-Ellison syndrome. $\beta$ cells (and hyperinsulinism) have been found in some patients with multiple endocrine adeno- 
pathy, ${ }^{2}$ but not in those with islet-cell lesions alone. Priest and Alexander ${ }^{25}$ have recorded specific $\alpha$-cell staining in their case but similar examples are few. Three cases have been reported in whom the syndrome was suspected but no pancreatic tumour was found. In the cases of Zollinger and McPherson ${ }^{39}$ and of Summerskilliso islet-cell hyperplasia was found on histological examination, but in the third case $^{33}$ there was no pancreatic lesion.

\section{Table II.-Islet-cell Tumours in Belfast (1939 To r958)}

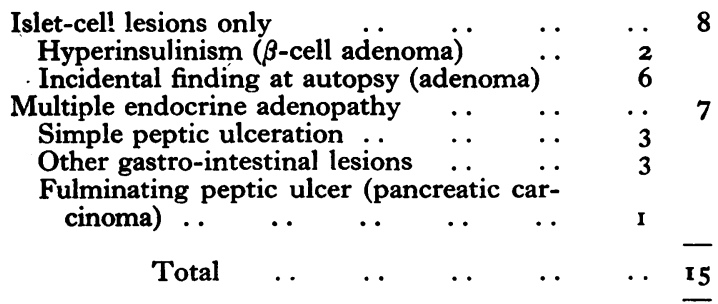

\section{Personal Observations}

We examined the hospital records and pathological material of 15 cases in which primary tumours of the islet cells had been confirmed (Table II). These were derived from approximately 82,000 biopsies and 13,000 necropsies, performed in 20 years on all types of cases from general hospitals in Belfast. No particular search had been made for pancreatic lesions and many minute adenomata must have been missed. For the detection of $\beta$-cell granules, Gomori's ${ }^{13}$ aldehyde-fuchsin stain was used. For $\alpha$ cells a modification of Gomori's ${ }^{12}$ chrome-alum-haematoxylin technique was used. Lendrum and Fraser's ${ }^{18}$ calcium chloride-phloxine-tartrazine sequence, originally introduced for carcinoid tumours, was substituted for the simple phloxine counterstain of the original technique. These methods were found superior in our material to a number of alternative techniques which were also tried.

We shall restrict our observations to cases with concomitant peptic ulcer or other disorders of the gastro-intestinal tract.

Peptic ulceration was recorded in three cases with multiple endocrine adenopathy. In two of these, a man of 42 and a woman of 63 , the endocrine lesions were extensive. Islet-cell adenomas were present in each case and neither tumour showed specific stainable granules. In the third case, a man of 62 , large haemorrhagic gastric and duodenal ulcers were associated with hyperplasia of pancreatic islets and with nodular hyperplasia of the adrenal cortex.

In three cases in the series pancreatic adenomas and lesions of other endocrine glands were found with other gastro-intestinal lesions. A large, welldifferentiated tumour which showed no specific staining of the cells was found at post-mortem on a girl of $\mathrm{I} 6$ who had been ill with severe vomiting and diarrhoea. Chronic gastritis and hyperplasia of the adrenal cortices were also found. In the second case, a man of 66 , suffering from severe acute colitis, was found at post-mortem to have multiple well differentiated islet-cell adenomata of the pancreas. Many of the cells took the stain for $\alpha$ cells. This case is an excellent example of multiple endocrine adenopathy; the adrenal cortices showed adenomatous hyperplasia, the pituitary contained chromophobe adenomata and the parathyroid oxyphil adenomata. A carcinoma of prostate was also present. In the third case, the pancreatic tumour may have played only an incidental role for the intestinal lesion was a carcinoma of the colon which had caused death by perforation of the bowel above. The pancreatic adenoma was large and moderately differentiated and showed no clear-cut specific staining reaction. The adrenal cortices were hyperplastic.

The only case of islet-cell carcinoma (associated with fulminating peptic ulcer) recorded in this series has been reported elsewhere. ${ }^{19}$

Thus the results of specific staining in our own series suggest that it is tumours of the $\alpha$ cells that occur in cases with concomitant gastrointestinal lesions. Since, however, the results were not sufficiently consistent to be convincing we were grateful of an opportunity of examining a number of other pancreatic islet-cell adenomata from other sources. Tissue blocks or unstained sections were kindly sent us by colleagues throughout the United Kingdom from six cases in which the tumours were associated with fulminating peptic ulceration or other manifestations of the Zollinger-Ellison syndrome. Staining for $\beta$-cell granules was negative in all instances. Positive $\alpha$-cell staining was obtained in four cases, the result was dubious in another, and negative in the sixth case.

The extent to which the tumours stained was variable but not capricious. Positive results were consistently obtained with well-differentiated adenomata of trabecular structure. Less differentiated tumours with a solid architecture were generally negative. The presence of the diffuse hyaline sclerosis mentioned above favoured the demonstration of $\alpha$ granules and well stained cells were sometimes found in peripheral parts of tumours showing this secondary change, while cells in unaffected areas gave an equivocal or negative reaction. There is no reason to doubt that the material stained by our technique is the same as that in the accepted method of Gomori on which it is based, and control of our method 


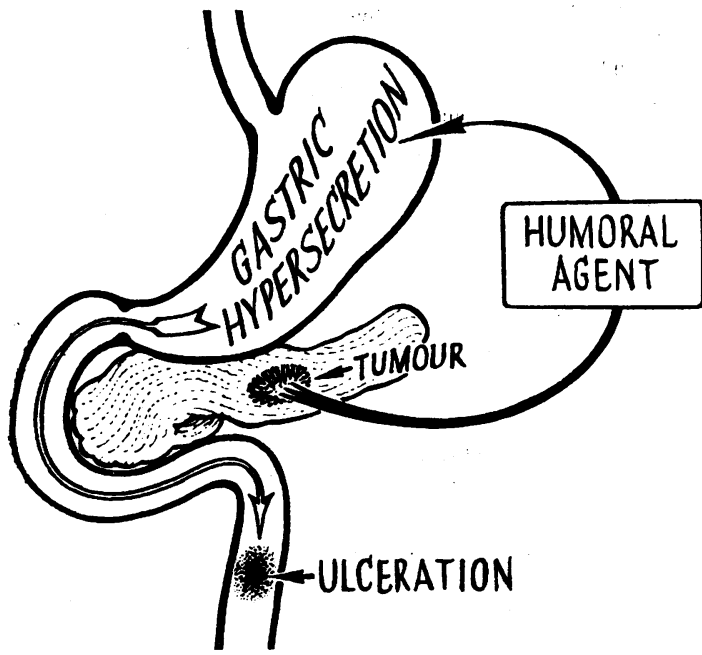

FIG. 3.-Possible inter-relationships in the ZollingerEllison syndrome.

on normal islets confirms its specificity. At the suggestion of A. G. E. Pearse (1959-personal communication) an attempt was made to demonstrate the indolic or tryptophane component of glucagon in the tumour cells by the method of Glenner and Lillie, ${ }^{11}$ but the reactions were weak and indefinite. The nature of the cellular content of the tumours in the Zollinger-Ellison syndrome remains as obscure as the identity of any substance they may secrete, but both are apparently similar to the products of normal ø. cells.

\section{Pathogenesis of Peptic Ulcer}

It is not yet certain how the fulminating peptic ulceration, gastric hypersecretion and islet-cell lesion that characterize the Zollinger-Ellison syndrome are related. The gastric hypersecretion probably causes the peptic ulceration, for total gastrectomy abolishes the secretion and cures the ulcers. ${ }^{24,30}$ The hypersecretion in its turn may be induced by a humoral agent for it is not abolished by vagotomy. A case reported by Dragstedt and his colleagues ${ }^{23}$ suggests that this humoral agent may be secreted by an islet-cell tumour (Fig. 3). After repeated operations (including three gastric resections and vagotomy) for duodenal ulcer and its complications the patient was left with a gastro-jejuno-colic fistula, and free acid persisted in the fasting gastric juice. Resection of an ectopic islet-cell tumour resulted in healing of the fistula and abolition of acid secretion. Similar but less striking cases have also been described. 6,10 To test this hypothesis, S. D. Clarke and D. W. Neill (personal communication) made an extract from an islet-cell tumour in a case with fulminant ulceration and injected it intravenously into a dog with a denervated gastric pouch. They werê unable to find any secretory activity.

Insulin and glucagon have both been considered as possible ulcerogenic agents, but there is little evidence in favour of either. Insulin can probably? be ruled out because most patients with hyper옫 insulinism do not have peptic ulcer and because hypoglycaemia is rarely found in this syndrome $\frac{\rho}{5}$ Glucagon may be secreted by some of the tumours because $\alpha$ cells are found in them, because a fevo of the patients have had hyperglycaemia ${ }^{6}, 19$ and because an extract from one tumour caused hyperglycaemia when injected into a rabbit. $\frac{\overrightarrow{2}}{\omega}$ It cannot be the cause of the ulceration, however because it inhibits gastric secretion. ${ }^{1}$

\section{Treatment of Zollinger-Ellison Syndrome}

Treatment must be directed towards both the peptic ulceration and the pancreatic tumour. Fof the ulcer Zollinger and McPherson ${ }^{39}$ now re $\vec{f}$ commend total gastrectomy in every case, be cause lesser procedures court disaster. The postoperative course of patients treated in this way $\overrightarrow{3}$ contrasts very favourably with that following par-w tial gastrectomy and vagotomy. ${ }^{24,30}$ However, inf view of the evidence which we have just discussed $\vec{\gtrless}$ a case can be made for a less radical procedi if it is reasonably certain that all the pancreacic tumour tissue has been removed. The treatmento of the tumour depends upon the findings. When -5 ever the syndrome is suspected the whole pancreaso must be mobilized, inspected and palpated both ino front and behind. Even when this is done, someo tumours will escape detection because of their $\overrightarrow{0}$ small size. It must also be borne in mind tha 8 many tumours are multiple and that some are in ectopic sites. The body and tail of the pancreaș contain two-thirds of the tumours and it is prob-o ably wise to resect this region, together with the 3 . spleen, in every case, whether or not a tumour is found. A tumour in the head may be enucleated. or excised; if it cannot be removed easily a forma pancreato-duodenectomy must be undertaken.

\section{Conclusion}

Islet-cell lesions may be associated not only with hyperinsulinism but also, when they formo part of the syndrome of multiple endocrine adeno- $N$ pathy, with simple peptic ulceration. Fulminating peptic ulcers are sometimes found in multiple $e_{\sigma}^{\omega}$ endocrine adenopathy and also in patients with $\alpha$-cell lesions of the islets but without disease of the other endocrine glands. This 'ZollingerEllison syndrome' should be suspected in any patient who has:

(I) Primary peptic ulcers, which are multiple⿳亠口冋 
or in unusual sites, especially in the lower duodenum or jejunum;

(2) Gross gastric hypersecretion (2-3 litres or more of highly acid juice in 12 hours); or

(3) A fulminating peptic ulcer which recurs rapidly after normally adequate surgery.

In any such patient a search should be made for endocrine lesions: a glucose tolerance curve should be obtained, the pituitary fossa should be X-rayed, the serum calcium and phosphate levels should be measured, the urinary tract should be X-rayed, and the adrenal steroid excretion should be estimated. Finally, at operation, the pancreas must be explored thoroughly. Treatment must be radical if it is to be effective.

\section{Acknowledgments}

We are grateful to those who have sent us pathological material for examination, namely, Dr. M. K. Alexander and Dr. W. M. Priest, Dr. J. R. Anderson and Mr. A. P. M. Forrest, Professor J. Bruce and Dr. J. M. Drennan, Professor T. Crawford and Mr. B. Pender, Mr. F. Forty and Dr. N. D. Gower, Mr. A. J. C. Latchmore and Dr. W. Goldie, Mr. L. LeQuesne and Dr. J. H. D. Slater.

We wish to thank Professor J. H. Biggart for allowing us to use his records, Mr. E. H. Crozier for technical assistance, Mr. G. A. Smith for the diagrams, and Miss $H$. Pountain for secretarial assistance.

\section{REFERENCES}

I. ClARKE, S. D., NEILL, D. $\mathrm{W}$., and WELBOURN, R. B. (1960), Gut, $\mathbf{1}, 86$.

2. CUNNINGHAM, L., HAWE, P., and EVANS, R. W. (1952), Brit. F. Surg., 39, 3 I9.

3. DONALDSON, R. M., von EIGEN, P. R., and DWIGHT, R. W. (1957), New Engl. F. Med., 257, 965.

4. DOTT, N. M. (1938), in 'The Hypothalamus', ed. J. C. Brash, p. 173, Edinburgh

5. DUFF, G. L., and MURRAY, E. G. D. (1942), Amer. F. Sci., 203, 437.
6. ELLISON, E. H. (1956), Surgery, 40, 147.

7. ELLISON, E. H. (1958), A.M.A. Arch. Surg., 77, 414.

8. EVANS, R. W. (1956), 'Histological Appearances of Tumours', pub. Livingstone, Edinburgh, pp. 513-520.

9. FISHER, E. R., and FLANDREAU, R. H. (1957), Gastroenterology, 32, 1075 .

I0. FORD, T. J., JORDAN, G. L., RICKSON, E. E., and FREEMAN, R. G. (1957), A.M.A. Arch. Surg., 75, 272.

I 1. GLENNER, G. G., and LILLIE, R. D. (1957), F. Histochem. $5,279$.

I2. GOMORI, G. (194I), Amer. F. Path., 19, 395.

13. GOMORI, G. (1950), Amer. F. clin. Path., 20, 665.

14. HOWARD, J. M., MOSS, N. H., and RHOADS, J. E. (1950) Int. Abstr. Surg., 90, 417.

I 5. HOWLAND, G., CAMPBELL, W. R., MALTBY, E. J., and ROBINSON, W. L. (1929), 尹. Amer. med. Ass., 93, 674.

16. JANOWITZ, M. D., and CROHN, B. B. (1951), Gastroenterology, 17,578 .

17. LAZAROW, A. (1957), Diabetes, 6, 222.

18. LENDRUM, A. C., and FRASER, D. S. (1959), f. clin. Path., I2, 37 I.

19. LOUGHRIDGE, J. S., and WILLIS, J. (1959), in press.

20. MACGREGOR, K. H. (1958), Amer. F. Surg., 96, 98. B. L., and SHNITKA, T. K. (1958), Canad. F. Surg., 2, 6.

22. MAYNARD, E. P., and POINT, W. W. (1958), Amer. F. Med., 25, 456 .

23. OBERHELMAN, H. A., NELSEN, T. S., and DRAGSTEDT, L. R. (1958), A.M.A. Arch. Surg., 77, 402.

24. PENDER, B. (1959), Lancet, i, 123.

25. PRIEST, W. M., and ALEXANDER, M. L. K. (I957), Lancet, $\mathrm{i}, \mathrm{I} 145$.

26. SHELBURNE, S. A., and MCLAUGHLIN, C. W. (1945), F. clin. Endocr., 5, 232.

27. SMITH, A. M., and COCHRAN, L. B. (1952), Lancet, i, 289.

28. SPENCER, H. (1955), F. Path. Bact., 69, 259.

29. STRÖM, R. (1953), Acta. chir. scand., 104, 252

30. SUMMERSKILL, W. H. J. (1959), Lancet, i, 120.

31. UNDERDAHL, L. O., WOOLNER, L. B., and BLACK, B. M. (1953), $\mathcal{Y}$. clin. Endocr., 13, 20 .

32. VERNER, J. V., and MORRISON, A. B. (1958), Amer. F. Med., 25, 374 .

33. WADDELL, W. R. LEONSINS, A. J., and ZUIDEMA G. D. (1959), New Engl. F. Med., 260, 56 .

34. WERMER, P. (1954), Amer. F. Med., 16, 363.

35. WERMER, P. (1958), Ann. intern. Med., 49, 1403.

36. WHIPPLE, A. O. (1938), f. inst. Chir., 3, 237.

37. WILDER, R. M., ALLAN, F. M., POWER, M. H., and ROBERTSON, H. E. (1927), f. Amer. med. Ass., 89, 348.

38. ZOLLINGER, R. M., and EllisON, E. H. (1955), Ann. Surg., 142, 709.

39. ZOLLINGER, R. M., and McPHERSON, R. C. (1958), Amer. F. Surg., 95, 359 .

40. ZUBROD, C. B., PIEPER, W., HILBISH, T. F., SMITH, R., DUTCHER, T., and WERMER, P. (1958), Ann. int. Med., 49, 1389 . 